\title{
The geography of spheres: an introduction and critical assessment of Peter Sloterdijk's concept of spheres
}

\author{
Huib Ernste \\ Department of Human Geography, Radboud University, Nijmegen, the Netherlands \\ Correspondence: Huib Ernste (h.ernste@fm.ru.nl)
}

Received: 22 October 2017 - Revised: 30 June 2018 - Accepted: 10 September 2018 - Published: 18 October 2018

\begin{abstract}
With his three-volume magnum opus on spheres, Peter Sloterdijk introduces a critical philosophical and cultural view of the spatiality of current society. His spatial metaphors serve as an intriguing source for inspiration for geographers. He describes the topological conditions of society by means of three different forms of spherical conditions of life: bubbles, globes, and foams. To understand, assess, and critique our current society we, according to Sloterdijk, need to replace the arrogant and cynical academic view of Plato and his followers with the more serene composure of the kinetic view of Diogenes. In this contribution, on the one hand we shall elaborate the spatial metaphor Sloterdijk uses. On the other hand we want to scrutinise Sloterdijk's ideas by drawing some parallels between his ideas and those of other philosophical anthropological thinkers. Finally, we very briefly want to point to a suitable conceptual framework for empirically investigating the spherology of human being in the world.
\end{abstract}

\section{Thinker of space and disputatious philosopher}

Peter Sloterdijk has written almost about everything, and in doing so has developed a great number of inspiring as well as provocative new ideas and new critical perspectives on old ideas. You love him or you hate him. He is sometimes accused of being a philosophical knock, knock, ginger prankster - a thinker who yells something and then quickly hides away. He loves to throw out some grand ideas, out of the blue, in a language which is bombastic, swollen and full of neologisms and with which he amuses but also confuses his audience. As Koen Haegens (2011) in a review essay in De Groene Amsterdammer once wrote, "when you read Sloterdijk you regularly get the feeling that with his wildest assertions he does not do justice to the facts. But before you are able to pin that down, the philosopher is already two, or three steps further in his argumentation", and you stay back, helplessly baffled. Carlin Romano (2012), writing for the The Chronicle of Higher Education, in the first instance describes Peter Sloterdijk as a hip European philosopher, choosing obscurity over clarity using abstract language and neologisms, the uglier the better, referring en passant to the endlessly interpretable giants of continental tradition, being prolific even if he does not have much to say, and rigorously avoiding clear-minded science, as if philosophy commands its own territory and outsiders must pay a literacy fee at the door. In the second instance he unveils some more of Sloterdijk's more substantial ideas. Peter Sloterdijk loves to provoke and to think the unthinkable and in eloquently doing so, he does not care for precision, thoroughness, or completeness. As such it is not surprising that the interviews he gave and public conversation he had are summarised in a book with the title Selected Exaggerations (2016a).

Even if his work seems to be rather eclectic and fuzzy, there is also a basic line of spatial argumentation in his work, which makes him, especially for geographers, a very interesting and inspiring thinker. In his magnum opus, the trilogy Spheres, the first volume of which was titled $B u b$ bles (2011), the second Globes (2014) and the concluding one Foams (2016b), he develops his main ideas about the spatiality of the human being. It has been attempted several times to summarise this more than 2500-page trilogy, but because of his style of writing, the many very diverse examples, and his ubiquitous use of neologisms, the secondary literature also presupposes a lot and is often difficult to digest for less philosophically engrained geographers, and therefore only addresses an in-crowd, who actually did not need it to 
gain access to the world of Sloterdijk. But as Nigel Thrift already noted, Sloterdijk writes as a philosopher, but to underpin his story, he draws on many empirical cases from a wide variety of sources (Thrift, 2009, p. 125). So he pretends to do more than just philosophy. I will, therefore, critically interpret his work from the social scientific perspective and look at it as a hypothetical social theory, based on philosophical insights, about the relation between human being, and space and place.

In this contribution I will briefly describe the main points of Sloterdijk's Spheres trilogy before I discuss some parallels and critiques. I will mainly focus on one important, but often overlooked parallel, namely with the philosophical anthropology of Helmuth Plessner. Peter Sloterdijk claims that his theory of spheres is an elaboration of the spatiality of Martin Heidegger's Being and Time (1927). Helmuth Plessner, as a contemporary of Martin Heidegger, already developed a spatial theory of human being and thus anticipated many of Sloterdijk's ideas. But if one compares them, an important critical difference with Sloterdijk's conceptualisation of spheres is also unveiled, which underscores the topicality of Helmuth Plessner's contribution to the current debate. The debate on the ontological foundations of current conceptualisations of the relationship between a human being and space is of course very important, but only indirectly helps geographers to do empirical research. We therefore need a more detailed conceptual framework with which we could address the different aspects of this relationship between a human being and space. For this purpose many different conceptual frameworks might be useful or could be developed further in these respects. In the last part of this contribution, as a very brief outlook, I will point to the current practice-theoretical turn as one possible promising conceptual framework for empirically investigating the role of spheres in today's society.

\section{The spatiality of Sloterdijk's spheres}

Sloterdijk's philosophical starting point is Martin Heidegger's Being and Time (1927), in which Heidegger dealt with the temporality of human existence (Dasein), which Sloterdijk tries to reformulate in a philosophy of Being and Space (Noordegraaf-Eelens and Schinkel, 2005). In doing so he also tries to criticise the dominant analytical and instrumental way of looking at the world, in which it is assumed that we can take the world apart and divide it up in its components and understand the causal relations between them, in such a way that we instrumentally manipulate the world in whatever way we like. It is this latter analytic and instrumental view which puts a human being as the manipulator of the world at the centre of the world and at the same time apart from it, from where he can rule the world. Sloterdijk tries to rethink our relation to the world by not starting with the individual in the face of the world, but by noting that to be human already implies that we are taking part in an intimate space that we share with other human beings and with other objects. In his view we cannot even think of ourselves if not as part of this sphere. This sphere is, however, not clearly demarcated or bordered, but is a rather diffuse feeling of connectedness. Spheres are affective orderings of living together (Boos, 2013, p. 55).

This affectivity is an important element in Sloterdijk's thinking about spheres. Like in all phenomenological approaches the embodiment of the human being plays a central role. The lived body (Leib) is the starting point and through embodiment we constitute the world. The lived body unites the physical body (Körper) with the mind, and therefore overcomes the separation of the physical outer world and mental inner world. They are both an integral part of the human lifeworld and cannot be segregated from each other. We observe the world through our bodily senses and through our bodily movements and observations, we make sense of the world, and we experience this sense in the form of a (spatial) ordering of experiences and meanings around our bodily being. We thus create a topology of our lifeworld, with regions closer by and regions which are at a further distance (Boos, 2013, p. 62). Sloterdijk extends this view by not putting the individual subjective embodiment, but the dividual con-subjective embodiment at the centre of his phenomenology of spheres. So it is not through our individual experience of the world, but through a joint clearing, conceding, and giving space (Einräumen ${ }^{1}$ ), a joint creation of a topological network of relations, that we create our sphere (Sloterdijk, 2012) ${ }^{2}$. The topological replaces the transcendental (Malpas, 2012, p. 78; Günzel, 2007).

The term "sphere" used by Sloterdijk in this sense is not thought of in a territorial way, but rather in a relational way. Maybe it is even better to compare it with a network of relations, which somehow caries us as human beings and in which human beings emerge as one node among others out of the densification of the network. This network, however, has no clear borders. Some relations reach further than others. Even though the metaphor of a network seems telling in this respect, Sloterdijk does not prefer the term "network", because, in his view, this still suggests too much that the human being is at the centre of this network. One could also associate the idea of a sphere with the idea of a rhizome of Gilles Deleuze. A rhizome can extend in all directions without having a clear core. As such, Sloterdijk's idea of this being, not as an isolated lonely creature, but as part of an intimate sphere, does not really allow the experience of

\footnotetext{
${ }^{1}$ The Erörterung of Ort (Placing of Place), or Einräumung of Raum (Spacing of Space).

${ }^{2}$ Jeff Malpas, however, notes that Sloterdijk takes up the issue of spatiality in his Spheres triology, but does this in a rather superficial way: "presenting itself as a new approach to space and place, it actually does little more than mobilise a set of spatial and topological tropes and ideas without ever interrogating their spatial and topological content or addressing the spatial and topological notions that they presuppose" (Malpas, 2016, p. 170).
} 
an "outside". There is no initial outside. The outside is at best something we create from the inside. So in the first instance we co-exist in a sphere, and only in the second instance do we exit as individuals differentiated from the outside other (van Tuinen, 2006, p. 48). According Peter Sloterdijk, in a sphere, we are never alone. A sphere is always a shared space. Dasein is always a being "with" and a being "within". The idea of an individual is, instead, a derived, secondary phenomenon. In the first instance we are not an individual, but as Nietzsche (1886) called it, we are a dividual $^{3}$. In the formulation of Heidegger the human being is inherently standing out in the openness of being, is ecstatic (van Tuinen, 2004, p. 55), and this is seen as structurally, immanently given. Sloterdijk therefore describes Dasein as ecstatic immance (2011, p. 625). As a dividual, we are more or less footloose within our sphere and are both here and there. Spheres thus are characterised by a multiplicity of different positions. Spheres inherently comprise more than one person, so they are by definition communities of dividuals. But this description also needs to be interpreted carefully. All too easily, one could assume that within a sphere there are two or more clearly distinguishable individuals or individual positions. Sloterdijk, however, assumes persons within a sphere to be real dividuals, to be inherently entangled, and part of each other.

The original idea of the philosophy of consciousness - that there is a real "I" which has a clear identity and position in the world and as such has a specific place in which it is at home, can feel intimately secure, and can be who it is - is an illusion according to Sloterdijk. Being in a sphere is an act of creation. Spheres, with their inherent multiplicities, challenge us to actively create a home for ourselves. Spheres, therefore, need to be taken care of and need to be created by ecstatic creatures who feel how the outside, the unfamiliar, the unfaithful, the strange and far away, which are socially constructed from the inside, affect them (Sloterdijk, 2011, p. 28). Through these creative actions, the human beings in a sphere jointly attempt to immunise and protect their sphere from the "monstrous" outside. This is not the act of an individual subject in the face of the big world out there, but an act of what Sloterdijk calls the "con-subject" seeking a secure home.

According to Sloterdijk, in our western thinking in terms of unities and substances and as independent knowing subjects, we seem to have forgotten the con-subjectivity and floating relationality of our being in the world (van Tuinen, 2004 , p. 91ff.). This shifts the subjectivity from the individual subject to the con-subjectivity of the sphere, or as Boos (2013, p. 69) formulates it in the terminology of Heidegger, "Through the shift from subject to Dasein the ini-

\footnotetext{
${ }^{3}$ What a dividual implies in psychological sense is more clearly explained by Mauthner (1906, p. 650ff.): a consciousness that comprises the here and now while at the same time having the ability to put oneself in the position of the other at another place and time.
}

tial perspective changes to the human community as a whole, from subject as producer of a lifeworld to the community as creative constructor of spheres of strong ties".

By the con-subjective immunising strategies, the sphere is to a certain degree being insulated from the outside world by creating shared norms and values of how to jointly deal with irritations and intrusions from the outside world. This usually takes place by means of a combination of internalisation, externalisation, objectivation, and routinisation (Boos, 2013, p. 73), and is described by Sloterdijk as the "air conditioning" of the sphere. This to a certain degree reduces the complexity of living together, but Sloterdijk immediately adds that this is not the general mechanism of complexity reduction, which Niklas Luhmann describes in his theory of social systems (Borch, 2013), because in his view human beings actually create a lot of complexity in dealing with each other and with their situation. And it is this complexity which also allows the con-subject to react creatively in different ways, in different situations, and on different occasions. In this way the sphere can also adapt itself to new situations and can even adopt and internalise parts of the outside world in its own sphere, partly also changing the character of the sphere as a whole. Or one could also describe this as the co-productive transmission of parts of the own sphere to the outside world, whereby the unfamiliar and distrusted outside is transformed into the familiar and trusted, extending the "comfort zone". One aspect of this complexity within a sphere is also that human beings taking part in this sphere are usually taking part in other spheres as well and thus are also actively involved in the transmission between these spheres. Taking care of the inside is inherently entangled with taking care of the outside. So irrespective of the continuous immunising strategies, spheres are never fully closed entities, but always comprise multiplicities (Elden and Mendieta, 2009, p. 7). Through this continuous creative production of spheres the "community" protects itself from the naked outside world, but also creates a positionality and identity which enables communication and interaction with and relating to the outside world (see also Fig. 1). Spheres, therefore, mediate between the inside and the outside. They are inner worlds which enable the human being to inhabit the outside world (Lemmens and Zwart, 2004, pp. 5-6).

If, through the step-by-step extension of the sphere into the outside, larger and more comprising spheres come into being. We thus might think of finally ending at the scale of a global sphere, an all comprising, total, overall, singular, borderless sphere. But according to Sloterdijk such a global sphere must be an illusion, as, following Sloterdijk, every de-bordering is accompanied by re-bordering, and as a consequence living together on a global scale does not reduce complexity but actually increases complexity as we cannot be unified under one single institutionalised normative whole. Sloterdijk outs himself here as a theorist of globalisation, and the Spheres trilogy becomes a historical description of different stages of globalisation and sphere making. 


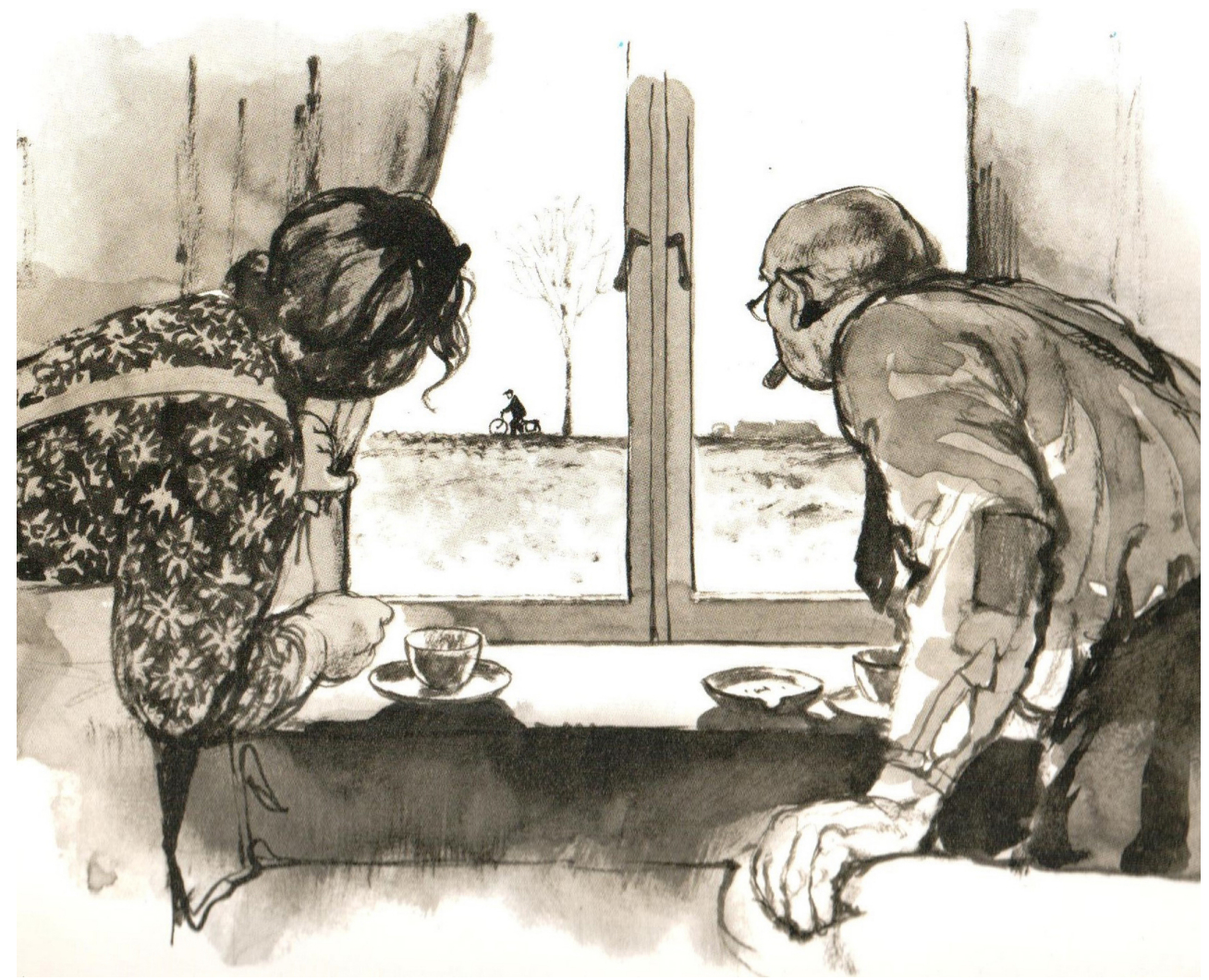

Figure 1. Relating to the outside world from a secure bubble. Aquarelle by Rien Poortvliet (1973) Te hooi en te gras. van Holkema \& Warendorf, Bussum. Source: Ernste (2016, p. 43).

\section{Sloterdijk's spherology and his plea for micro-politics: Bubbles, globes and foams}

In Bubbles (2011) Peter Sloterdijk develops his ontological view that the human being is never alone, but is always accompanied by other human beings and things in a shared living space. To underpin this thesis he goes back to being born into this world, through which the original intimate relationship with the mother, is broken up, and to the experience of floating in and with each other and of being in between (p. 139). The original double-unity of mother and child is described as a pure inner space without an outer space. In this pre-birth primal sphere we could speak of a pre-eminent con-subjectivity. Being born into this world in this respect is a primordial catastrophe, which is the exemplary event for all later destructions and transformations of spheres (van Tuinen, 2006, p. 54), which causes our lifelong search for new relations, or as Sloterdijk calls it, new mediated resonances. To speak with Marijn Nieuwenhuis (2014, p. 21): "The longing for the perfect union in the bubble of the broken womb will, as we are told, throughout the subject's lifetime compel her to travel, create, and dwell in many different spheres". By suggesting this con-subjectivity as a kind of pre-subjectivity Sloterdijk also counters the classical philosophical idea that we should start thinking from the premise of a subject-object dichotomy. Subject and object are not divided, and a new view of cultural and natural objects, which comprise a sphere, comes about. In this microsphere we become aware that everyone and everything we encounter takes part of us or takes part in us, and we experience ourselves as a penetrable and receptive body. In the view of Sloterdijk (2011, p. 94), this, by the way, also disqualifies the enlightenment dream of human autonomy, and individuality and the myth of modernity assuming humans as individuals in harsh competition for survival in a state of war, based on the anthropology of a "pure", "born alone", "solitary" individual without any "being with" (Couture, 2009, p. 158). The neglect of the individual or the subject is not new and can also be observed in the thinking of Niklas Lumann's Social Systems Theory, and for example in the work of Michel Foucault and his followers. Both of them emphasise communication and discourse rather than individual subjectivity. Sloterdijk, however by and large replaces communication with imitation, a term he borrows from Gabriel Tarde (1903), related to the non-linguistic contagious-affective relationships between con-subjects, which Tarde describes as a kind of somnambulistic suggestion. "The individual and his or her desires, inclinations, gestures, etc., are seen as hypnotically transmitted and therefore not specific or characteristic to the individual in question" (Borch, 2009, p. 229). Imitation be- 
tween members of a sphere founds a kind of anonymous "group mind". The individual is thus nothing more than a node of various rays of imitation. This kind of mimetic suggestion thus undermines the notion of individuality and at the same time emphasises affect rather than deliberation and conscious choices and purposive action.

In Globes (2014), in the wake of Friedrich Hegel (Phenomenology of Spirit) and Oswald Spengler (The Decline of the West), Peter Sloterdijk provides us with a morphological history of globalisation by distinguishing three periods of globalisation - the metaphysical, the terrestrial, and the contemporary period of foams (Morin, 2009, p. 58). The first metaphysical phase of globalisation is, according Sloterdijk, based on the conviction that the best strategy with which to immunise the interior is by integration of the outside. "In this phase, the goal of human existence is the construction of a metaphysical globe, an all-encompassing sphere in which humans could find a sense of security, of immunity. By swallowing up the outside, this absolute totality (under the form either of a cosmos or of a God) is supposed to be in a position to offer absolute immunity to its inhabitants" (Morin, 2009 , p. 62). The internal ordering is prescribed by its final Aristotelian cosmological teleological structure striving towards perfection, where everything has its assigned place. Also, the politics in such a spherical community would be directed towards keeping everything turning around its centre (Morin, 2009, p. 63). With this objective, the individual is subordinated to the divine centre. In the classical metaphysics to protect the mortal individual one assumed the eternal, which actually ignores every individuality. In face of God we are all equal. This logic does not really change after Kant's Copernican turn, because it then becomes reason which directs us towards the anticipated transcendental idea of a universal whole (as if we know what the world is teleologically directed to). The kind of politics related to this view is the politics in which the particular and local being is replaced by being a citizen of the whole, of the cosmopolis, and being part of a world government or a universal culture. According to Sloterdijk and following Nietzsche, however, such a creation of a total immune sphere is deemed to fail, because it lacks a unifying outside. An absolute sphere with no outside, or to repeat a dictum of Blaise Pascal, "an infinite sphere whose centre is everywhere and whose circumference is nowhere", cannot be used by anyone to create a sphere of intimacy. Instead of offering absolute protection, it ends up offering no protection at all and negates all human demands for immunity (Sloterdijk, 2014, pp. 526-528 as quoted in Morin, 2009, p. 64).

The metaphysical focus on the eternal whole changes slowly but surely, according to Sloterdijk, with the discoveries of Copernicus. From then on, one did not so much seek a spiritual whole as an eternal sphere, but one sought a terrestrial, territorial whole as a global sphere. The vertical transcendence is now replaced by a horizontal transcendence, implying the conquest of the outer world. God seekers become state seekers (van Tuinen, 2006, p. 57). By means of imperialistic strategies that are used to conquer the world, one tried to accommodate and assimilate the outside into an inside. One wanted to control the whole world. Microspheres thus coalesce to macrospheres. But also in such a global sphere one is bound to fail, as, without an outside, the destructive influences come from the inside. Larger communities, therefore, do not automatically lead to greater immunity, as, according to Sloterdijk, was shown by the fall of the Roman Empire (van Tuinen, 2006, p. 58).

In Foams (2016b), he describes how we break with these globalising tendencies when, through the immense speed with which goods, human beings, capital, and information flash around the globe, we lose our centre and notice that where everything has become a centre, we do not have a valid centre anymore. The virtual space has become the overall outside, which cannot be internalised anymore (Sloterdijk, 2011, p. 66). We become footloose and homeless. In this third phase of globalisation, we lose the typical spherical form or being in the world and our existence becomes rather formless, which Sloterdijk tends to describe as foam, an irregular agglomeration of bubbles. As Morin (2009, p. 67) describes it, "each bubble is a "world", a place of sense, an intimate room that resonates or oscillates with its own interior life" while at the same time being connected to all other bubbles and therefore highly interdependent of each other. It could be described as the connected isolation of living apart together in a system of co-fragility and co-isolation (Morin, 2009 , p. 67). From the inside of each foamy bubble, one does not have a view of the whole, but only on the adjacent bubbles. In contrast to the metaphysical or terrestrial globes for these foamy bubbles, there is an overall outside, and for every outside is a related outside from which one is not fully immunised. Without this overall outside there can also be no ruling from the whole to the multitude of its parts, or resistance from the parts towards the whole. "Each bubble resists its dissolution and integration into a whole or a uniform sphere but without being opposed to or directly fighting against it since each of them requires the whole for its own stabilisation" (Morin, 2009, p. 68).

Sloterdijk also characterises the topological structure of these foamy spheres " ... closely bound to the hominisation process: chirotope (the hand accessible domain), phonotop (the vocal bell under which coexisting beings listen to each other), uterotop (the maternal zone and its early social metaphorisation), thermotop (the heated circle of comfort), erotop (the place for primacy erotic energy transfer), ergotop (the shared spirit of cooperation in common work), aethotop (the continuity of the collective world view), theotop (the space of revelation for elders and gods), and nomotop (the social architecture and its political constitution). These are seen as the promising fields of inquiry for any future spatial analysis of humans as in-world insulated creatures" (Couture, 2009, p. 162). In retrospect, this seems very much an inside-oriented topology, and one is tempted to think of ad- 
ditional or alternatives ways of describing and categorising such a spherological topology.

Human beings in these foamy spheres will need to take care of themselves from these small foam-bubbles. They need to position themselves or are being positioned in these topological structures. This is, therefore, not big politics but small politics (van Tuinen, 2004, p. 83). The conservation of the personal foam-bubble then becomes a condition for solidarity. This kind of self-care or limited care stands in stark contrast to the global responsibility of taking care of the whole even if it implies acting against one's own particular interests (van der Ven, 2002, pp. 503-507). In contrast to classical politics, the politics in foams does not address the belonging to an overall whole, but is a politics of selfregeneration and self-continuation that Sloterdijk calls "hyperpolitics" (Morin, 2012, p. 68). This is a shift from macromanagement to micromanagement. Accordingly Sloterdijk pleads for a politics of dispassionateness, or to use a phrase borrowed from Georg Simmel, of a disengaged blazé political attitude, towards other spheres. This is a light, frivolous and floating attitude, opposing the heavy, demanding and pressing character of the totalising pretentions of the global whole.

In the following I want to focus on an alternative view of the ontological aspects of the concept of spheres and leave the issue of a theory of globalisation aside, which is how Sloterdijk's spherology is also read.

\section{An alternative spherology: The philosophical anthropology of spheres}

Although Sloterdijk's writings are very baroque and evocative and therefore thought provoking and inspiring, his thinking is to a large degree not totally new and finds many parallels. Even in writings he fully ignores or tends to criticise. Without going into the nitty gritty details and without the pretention of completeness, which anyhow is also not Peter Sloterdijk's style, let me just observe a number of them and discuss the issues for debate related to them.

Peter Sloterdijk usually presents his ideas by lustfully breaking all kind of taboos, sometimes even causing a scandal. If one reads his texts closely, it is striking how many valuing adjectives he uses, without really underpinning these implicit judgments. The inherent provocation lets it sound as something totally new and unheard of, but the basic philosophical ideas he presents are to a large part not that new at all. For example, already in the 1920s, in the year after the publication of Heidegger's Being and Time, the German philosopher Helmuth Plessner designed a general theory of being and space and created an alternative philosophy of human being, through which he also revised the traditional European humanism. With his book Die Stufen des Organischen und der Mensch (1975 [1928]) he formulated from a critical-phenomenological point of view a philosophical an- thropology from a spatial perspective. Interestingly enough, Peter Sloterdijk does not seem to mention or acknowledge Helmuth Plessner at all, but that is not to say that he fully ignores Helmuth Plessner's work, even though he, as a philosophical glutton, must be well aware of it (van Tuinen, 2004, p. 103). The Helmuth Plessner Association, on the other hand, together with the municipality of Wiesbaden (the place where Plessner lived for a long time) awarded Peter Sloterdijk the Helmuth Plessner prize 2017, but not without creating a scandal within the Helmuth Plessner Association itself. So, one is tempted to say that therefore the bubble around Sloterdijk seems to have a hypnotic mimetic effect on the bubble of Helmuth Plessner scholars almost in a spherological way.

In the heydays of philosophical anthropology in the 1920s, under the influence of the revolutionary developments in the natural sciences in the second half of the nineteenth century, it was the main endeavour of the philosophical anthropology to rethink the special position of the human being and teleologic phenomena, by either assuming an Aristotelian notion of entelechy denoting the vital function, of a living organism, which actualises a vital potential and gives form to the matter it is comprised of (Hans Driesch), or by assuming a divine spiritual metaphysical dimension (Max Scheler) (de Mul, 2014, p. 458). It is this kind of philosophical anthropology which came under attack after World War II with opposition to its alleged essentialism and anthropocentrism (de Mul, 2014, p. 461). The philosophical anthropology of Helmuth Plessner is, however, of a different kind. To a large degree he accepted the materialistic and mechanistic world view, but at the same time gave a critique by asserting that this clarifies "how the vital and psychic functions of living organisms are being materialised, but not what life in its subsequent stages and various expressions is" (de Mul, 2014, p. 459). In the same way, he was also critical about the transcendentalist position of Scheler and Driesch. Similarly to Sloterdijk he assumes that being in the world, being alive, presumes a unity between the material and the psychological.

On this basis, Plessner develops important categories of human life and of the human being in the world from a spatial perspective (see also the more elaborate account in Ernste, 2004 and 2014). He describes how human beings on one hand live a centric life and are centrically positioned, at the "centre" of their body and distinguished from the environment by a clear boundary, from which the human being is directed towards their environment. On the other hand, human beings live an eccentric life or are eccentrically positioned, from where they can look back on themselves and on their situation but also look outward as if it is part of their inner life. This is not "a reproduction of the Cartesian dualism with its separation of bodily existence and human consciousness. On the contrary, it is an essential element of Plessner's theory that these are two sides of the same coin" (Ernste, 2004, p. 444) or what he denotes as double aspectivity. From this 
perspective human beings are always aware of the contingency of their current centric positionality, or one might also say that they are simultaneously aware of the inside and of the outside. They are having a directed relationship with their immediate environment (Umwelt) but at the same time also have a view of the world at large (Welt). Interestingly enough, the boundary which envelops us, according to Plessner, is not an immunising protective mechanism, but always an interface, which hides certain aspects from the outer world, but which is also a projection surface through which the human being expresses itself to the outer world and is depicted by the outer world and through which it gains identity and individuality. It is the medium through which the person's topological being in the world is constituted (Malpas, 2017, pp. 8-9). In contrast to Sloterdijk, Plessner refrains from using many judgemental adjectives, and his phenomenological analysis allows different conclusions. Sloterdijk seems to build a picture of a monstrous outer world, from which we can only expect threat and danger against which we tend to immunise, while for Plessner boundary work always has two sides. One the one hand it distinguishes and isolates us, but on the other hand it relates and opens us to the outer world. While Sloterdijk assumes that we feel safe and comfortable within our immunising boundaries, therefore implicitly essentialising our positionality, Plessner notes that from our eccentric position, we are always aware of the uncomfortable narrowing limitation, localisation and temporalisation of our centric positionality and thus can never feel truly at home. We are thus bound to continuously reinvent and recreate our centred being without ever losing the basic human experience of the contingency of our being in the world. So there is no such thing as an immunised place we can call home and therefore also in the foamy globalising world of Sloterdijk, there is no such thing as conflict-free acquiescence towards neighbouring and related spheres. Plessner describes human being in the world in a non-essentialising way as homo absconditus, the hidden human being, or to paraphrase a famous quote of Robert Musil (2017), as "a human being without qualities".

Being human in this world therefore does not just let us retreat behind immunising borders but actually lets us transgress these borders and venture into the world and encounter "the other", seeking a place where we can be what we are as human beings in this world. Our openness to the world is not monstrous, but part of our dwelling, or our home. The parallels with Sloterdijk are striking, but the nuanced differences in conceptualisation and valuation are also apparent. One other difference between them seems to be the focus on the affective aspects of the sphere in the work of Peter Sloterdijk, in contrast to the focus on conscious reflexivity in the work of Helmuth Plessner. While Peter Sloterdijk, following the work of Hermann Schmitz (2007, 2010, 2011), decentres the affectivity from the individual subject to the sphere, where it also figures as an emergent relationships between different persons, without any conscious intermediation of the individual subject (Demmerling and Landweer, 2007; Fuchs, 2000), Helmuth Plessner preserves the subjective cognition and centred performativity of the individual human being, without excluding affective relationships. This is also clearly reflected in his The Limits of Community: A Critique of Social Radicalism, first published in $1924(1999)^{4}$. In this writing he reacts to Ferdinand Tönnies' ground-breaking book (2011 [1887]) Community and Society but also to the societal and political circumstances of those times, which seem to a certain degree to resemble current conditions. When Helmuth Plessner was writing, these were the first years of the Weimar Republic, with unstable conditions, intense resentment against the rule of law and against democracy, pressing reparation payments, galloping inflation, and the Hitler Putsch in 1923. In those times, both from the left as well as from the right, extremist calls could be heard, which often also used the call for community. These were radical times (Hellmann, 2008, p. 2). The similarities with current times, with economic uncertainty, political moroseness, populism, xenophobia, protectionism, and no-future youngsters is obvious, and is partly also related to the failed globalism Sloterdijk is describing in his Spheres trilogy.

In exactly these circumstances Plessner felt the call to write his critique against social radicalism, which tends to glorify the community, the "we" against the evil others and which also tends towards an imperialistic moral radicalism. Plessner sees it as a strength under these circumstances to vote for society instead of community. Society demands much more from the individual human being than a community, which tends to take the individual under one's wing and therefore obliterates the individual (Hellmann, 2008, p. 3). The (affective) intimacy which is presupposed in these communitarian spheres cannot simply be superimposed onto modern or post-modern societies, which with their functional differentiation anyhow demand a different regime for selfcontrol. And as Plessner states, the idea of such a communitarian sphere is anyhow an illusion, since even in archaic communities the complete resorption of a person by the community does not exist. Even in these situations, for the sake of human dignity, a minimum of individuality, non-shared intimacy and privacy is needed. So Plessner does not oppose the idea of community in general, but points to its limits. To cope with these limits, Plessner suggests, in a rather pragmatic way, that we should look for compromises with each other and in relation to the unknown "other", even if it were the devil, instead of the mere idealistic blissful repulsion. It is important to note that for Plessner the possibility for the political in society is based on the anthropological conditions of a human being in the world and is not just based on his diagnosis of the historical situation at that time (Edinger, 2017, p. 327). For Plessner community and society are inviolably dialectically united. The political is just one side of Pless-

\footnotetext{
${ }^{4}$ See also Eßbach et al. (2002).
} 
ner's social ontology of everyday Dasein (Krüger, 2016). On this basis, Gesa Lindemann developed the concept of a reflexive anthropology (Lindemann, 1999), in which both the anthropological conditions of human being and the historical situation are openly reflected and can be politicised.

With respect to the critique against the imperialistic idea of a global community, Peter Sloterdijk and Helmuth Plessner are in one line. But with respect to the alternative, they clearly differ. While Sloterdijk opts for a conceptualisation of the (post-)modern world as a world of foams and suggests small politics and an attitude of composure and limited solidarity. Helmuth Plessner, in my interpretation, would opt for large politics with awareness of the limitations and contingencies and therefore without essentialising a transcendental whole. Bude and Dürrschmidt, in a thought-provoking paper based on Plessner's conceptualisation of human being, also ask themselves "What's wrong with globalisation?" and come to the following insight.

"though as a bodily existence always deeply entangled in the here and now, man is also "ahead" of himself in terms of reflexive distance towards here and now. Structurally he lives in an open horizon of possibilities, pressured to solidify some of them into existence by his ultimately final life trajectory (Plessner, 1975, p. 343). It is this unalterable human condition of "eccentric positionality", or as one might also refer to it, as a "half-opened being" (Metcalfe \& Ferguson, 2001), which forces him to "lead" a life in the most literal meaning of the word (ein Leben "führen")" (Bude and Dürrschmidt, 2010, p. 494).

So instead of opting for a politics of the non-human, in the course of the post-phenomenological (Ash and Simpson, 2016, p. 63) thrust towards embodied consciousness - a rather contradictory move as it lets the component of consciousness disappear from the embodied consciousness - Plessner opts for a real double aspectivity of the embodied consciousness (Richter, 2005).

These different ontological assumptions and historical diagnosis are also at the core of the fierce debate between Peter Sloterdijk and Jürgen Habermas. In the first instance this seemed to be only about the Nazi-tainted provocative statements of Peter Sloterdijk in the lectures he gave in 1997 and 1999 that had the title Rules for the Human Zoo: A response to Heidegger's letter on humanism, and contained words like Züchtung (breeding) and Selektion (selection) and references to the "failure of humanism", but on the bottom line, the dispute was about Habermas' observation of Sloterdijk's seeming move to radical neo-conservatism with a whiff of fascism and eugenics as well as hatred of democracy, related to it (Romano, 2012). This shows that the political geographic implications of Sloterdijk's thinking are far from neutral, as Benedikt Korf and Doris Wastl-Walter (2016, p. 106) tended to describe it, and need, in general, to be critically scrutinised.

Given this critique and alternative conceptualisation of the human being in this world, one may ask whether there is a conceptual framework which can be operationalised and applied in the field of geography in such a way that it allows comprehensive empirical research into the spatialities and everyday practices of spheres, which potentially could take into account the double aspectivity of a human being in the world. Based on this critique, it is clear that contrary to Sloterdijk, Helmuth Plessner does think of spatiality and of the political aspects of speciality in a much more relational and procedural way. Being human for Helmuth Plessner implies that one is already beyond one's own cocoon, and beyond the strategies of immunisation, and therefore to be human brings with it, to be a zoon politicon, which is constitutively entangled with the "mutual world" (Mitwelt) (Hetzel, 2005, p. 236). As such this is a plea for an even more radical relational thinking in human geography and for conceptualising these relationships in a fundamentally political fashion. Obviously, currently in the field of geography fashionable relational approaches (complexity theory, actor network theory, assemblage theory, practice theory, mobility theory) are a good starting point. In the following I very briefly focus on one of them, namely practice theory.

\section{Investigating spatial practices and spheres}

Although practice theory ${ }^{5}$ is not presented as a theory of spheres as such, but rather as a social theory grasping the complexities and ambivalences of our being in the world, it is formulated in a less polemic and better underpinned way than Sloterdijk's theory of spheres. (Schatzki, 2001, 2012; Reckwitz, 2002; Everts et al., 2011; Schäfer, 2016). Although practice theories come in many different forms and are interpreted in different ways, a number of key elements show that some parallels can be found between Peter Sloterdijk's spherology, Plessner's view of human spheres and current praxeological approaches. Of course there are also some differences and tensions, which I will not deny. In this section of this contribution, I would like to point to those parallels and underscore the potential compatibilities. Since there is already a rich field of empirical applications of this praxeological approach in the geographical field, this praxeological approach, or a further developed version of it, might also be helpful in operationalising and critically investigating how human spheres emerge, develop, and are politicised.

Like Sloterdijk's attempt to conceptualise the being in the world from a relational, topological perspective, practice theory does this based on the concept of every day practices, which creates the dynamic topologies of the human being and human positioning. What Sloterdijk tends to circumscribe as spheres is conceptualised as practical situations,

\footnotetext{
${ }^{5}$ For an overview see also Nicolini (2013).
} 
or "sites" of the social (Schatzki, 2002) in practice theories. Crucial to Schatzki's version of practice theory is that he clearly shows how, on the one hand, these theories of practice also decentre human subjectivity to the practical situation. They position subjectivity in relation to the practical situation and therefore move in the direction of a posthumanist view, but on the other hand they still defend a residual humanism, in the same way as Helmuth Plessner, based on his concept of double aspectivity, and therefore do not release the subject from a boundary transgressing political responsibility (Ernste, 2004). The topological arrangements, according to Schatzki (2002), impute, prefigure, and lead to agency, a necessary agency, because human activity is fundamentally indeterminate and inherently contingent. Although, some scholars of practice theories only refer to this aspect of decentring of the subject, as agents formed by the structures of practice, I think that this interpretation does not do justice to the ontological assumptions of the subject on which Schatzkian practice theory is based, which also find their parallels in "Heidegger's early conceptions of thrownness and of the priority of involved practical dealing over reflection and theory; in Wittgenstein's account of rule following and in his conviction that action underlies language, thought, and reason; in H.-G. Gadamer's notion of continuous concept formation; in Derrida's and Judith Butler's notions of the performative citation of norms; and in what [Schatzki is] calling the "indeterminacy" of action" (Schatzki, 2002, p. 233). Here I see a great opportunity for a mutually constructive debate between practice theory and the Plessner-inspired theory of "approaches to the world" as formulated by Gesa Lindemann (2014), in which practice is not prioritised over reflection, but human practices are themselves conceptualised as reflective.

A typical element of practice theories is that they explicitly address the "change" of practices in everyday life (Shove, Pantzar, and Watson, 2012). They deal with small shifts but also with larger transformations. So without being presented as a theory of globalisation, as Peter Sloterdijk implicitly does in his Spheres trilogy, practice theories do provide a very open conceptual framework in which to address these changes, without precluding in what direction these changes take place. From this view of the dynamics of practices, human spheres (Lindemann, 2017) are seen as emergent and becoming and are therefore also in a process of continuous negotiation with "the other" in different settings and at different times.

Practice theory takes practices, rather than individuals or whole societies, as the primary unit of investigation and analysis. Distinguished practices can be viewed as practices of being in the world, or as Sloterdijk would probably express it, as practical sphere making. Sloterdijk conceptualises spheres as affective communities in which the affective bondage in relation with a specific spatiality plays a central role, and in a similar way Andreas Reckwitz (2012) conceptualises these affective spaces from a praxeological point of view. Practices then become constitutive for the development of affective spheres. Like a sphere, a practice consists of socially embodied activities ("sayings and doings") combined with material arrangements and linked into a nexus by understandings ("knowing how to carry out desired actions"), rules ("explicitly formulated directive, remonstration, instruction, or edicts") and teleoaffective structures ("ends, projects, tasks, purposes, beliefs, emotions, and moods") (Schatzki, 2012). One could say that these concepts describe the topological structure of practices, including the human beings taking part in it. Although practices are social entities, they are performed by individual carriers who actualise and sustain these social entities. "[P]ractices not only generate emotions, but [...] emotions themselves can be viewed as a practical engagement with the world. Conceiving of emotions as practices means understanding them as emerging from bodily dispositions conditioned by a social context, which always has cultural and historical specificity. Emotion-as-practice is bound up with and dependent on "emotional practices"” (Scheer, 2012, p. 193). In these practice theories it is essential that practices are executed by knowledgeable human beings, but this individual bodily subject according practice theory emerges from social practices in which bodies and things are mutually entangled through emotional relationships. These practices are never just limited to the boundaries of a sphere or situation but reach well beyond them. At the same time, as human beings, we are always involved in many different practices on different scales and in many different political frames, from local foamy spheres to global globes, or to be more precise, we as human beings are continuously creating and taking part in different spheres and thus are creating and taking part in different places. As such we are never just within a sphere but always also beyond that sphere.

In practice theories the choices people make in these situations are addressed from a pragmatic point of view and there is an attempt to reconstruct human activities as practical sensemaking in those specific situations. This somehow suggests that a suitable fit between (political) choices and practical situations, or current and local practices is feasible. However, if practice theory fully took into account the double aspectivity of the human being in the world as suggested by Helmuth Plessner, it would also need to address the inherent homelessness of the human being in these situations. Making sense of a practical situation is an act of meaning making, but as a consequence of the double aspectivity of the human being, meaning needs to be defined as the "unity of the difference between actuality and potentiality" (Henkel, 2016) of the difference between the actual and the virtual (Delanda, 2005). So the pragmatics of "meaning making" in practice theories sometimes still tends to partly disguise the political aspects of everyday practices and the insufficiencies of everyday compromises too much, but on the other hand, a broader conceptualisation of meaning could also serve as a framework in which to address them without taking a position beforehand too easily. The pragmatist con- 
ceptualisation of human practices in current practice theories would at least allow this and could foster the further development of these practice theories in these directions, which could prove to be very promising and useful for geographical research. As such, current practice theories (Hui et al., 2017) seem to provide a comprehensive framework for productive geographical research on spheres of human being and human activities.

\section{Conclusion}

In this contribution I have in the first instance tried to give a brief overview of some of the core aspects of Peter Sloterdijk's inspiring endeavour as put forward in his magnum opus, the trilogy Spheres. This endeavour also evoked a lot of critique, which partly target his style and performance but also address some of the core issues of his theory. Without pretending to be comprehensive or complete, I highlighted some of those critiques, not so much from a philosophical but more from a critical social theoretical and geographical perspective. But critique is always easy. More difficult is offering an alternative. In this contribution I showed that the philosophical anthropological perspective of Helmuth Plessner offers us a well founded and well underpinned alternative phenomenology of the human spatial being in the world, with far-reaching political consequences of how to deal with the current state of globalisation. Second I suggested that current practice theories, also offer us a good alternative social theoretical conceptual framework, to investigate, the kind of relationalities and topologies, which Sloterdijk suggests, but which he approaches from a rather one-sided and sometimes even flawed angle, without an elaborated and critical conceptualisation of these relations. Practice theories themselves do not really take a critical stance themselves, but allow elaboration of the multidimensional complexities of the political choices and positionings constantly made in everyday practice. As shown above in certain aspects, practice theory is still not radical enough in its relational thinking according to Plessner, since it still seems to think of human beings as elements in practices, instead of the human being as a relational phenomenon, with all the inherent political aspects of that relationship. Practice theory is seemingly apolitical, but this openness or indeterminateness makes it an especially good candidate for developing further in the direction of Plessner's alternative spherology, so that the politics of spheres and of human spatiality becomes much more apparent. These potentialities still need to be put in practice and are thus far from ready to use, and will need further elaboration along the lines suggested to come up with a fully fledged alternative theory of Spheres and a mature framework for empirical geographical research on the practices of sphere making.

Data availability. No data sets were used in this article.
Competing interests. The author declares that he has no conflict of interest.

Acknowledgements. I am very grateful for the very useful comments from the editors of this special issue on an earlier version of this contribution.

Edited by: Benedikt Korf

Reviewed by: two anonymous referees

\section{References}

Ash, J. and Simpson, P.: Geography and post-phenomenology, Prog. Hum. Geog., 40, 48-66, 2016.

Boos, T.: Ethnische Sphären, Über die emotionale Konstruktion von Gemeinschaft bei syrisch- und libanesischstämmigen Argentiniern, Transcript, Bielefeld, 2013.

Borch, C.: Organizational Atmospheres: Foam, Affect and Architecture, Organization, 17, 223-241, 2009.

Borch, C.: Spatiality, Imitation, Immunization: Luhmann and Sloterdijk on the Social, in: Luhmann Observed, Radical Theoretical Encounters, edited by: la Cour, A. and PhilippopoulosMihalopoulos, A., Palgrave Macmillan, Basingstoke, 150-168, 2013.

Bude, H. and Dürrschmidt, J.: What's wrong with globalisation?: Contra "flow speak" - towards an existential turn in the theory of globalization, Eur. J. Soc. Theory, 13, 481-500, 2010.

Couture, J. P.: Spacing emancipation? Or how spherology can be seen as a therapy for modernity, Environ. Plann. D, 27, 157-163, 2009.

Delanda, M.: Space: Extensive and Intensive, Actual and Virtual, in: Deleuze and Space, edited by: Buchanan, I. and Lambert, G., Edinburgh University Press, Edinburgh, 80-88, 2005.

Demmerling, C. and Landweer, H.: Philosophie der Gefühle, Metzler, Stuttgart, 2007.

de Mul, J. (Ed.): Plessner's Philosophical Anthropology, Perspectives and Prospects, University of Amsterdam Press, Amsterdam, 2014.

Edinger, S.: Das Politische in der Ontologie der Person, Helmuth Plessners Philosophische Anthropologie im Verhältnis zu den Substanzontologien von Aristoteles und Edith Stein, de Gruyter, Berlin, 2017.

Elden, S. and Mendieta, E.: Being-with as making worlds: the "second coming" of Peter Sloterdijk, Environ. Plann. D, 27, 1-11, 2009.

Ernste, H.: The pragmatism of life in poststructuralist times, Environ. Plann. A, 36, 437-450, 2004.

Ernste, H.: Eccentric Positionality and Urban Space, in: Plessner's Philosophical Anthropology, Perspectives and Prospects, edited by: de Mul, J., University of Amsterdam Press, Amsterdam, 243 260, 2014.

Ernste, H.: Klassieker: Over de relatie tussen mens en de ruimte, Agora, 32, 42-43, 2016.

Eßbach, W., Fischer, J., and Lethen, H. (Eds.): Plessners "Grenzen der Gemeinschaft” Eine Debatte, Suhrkamp, Frankfurt am Main, 2002. 
Everts, J., Lahr-Kurten, M., and Watson, M.: Practice Matters! Geographical inquiry and theories of practice, Erdkunde, 65, 323334, 2011.

Fuchs, T.: Leib, Raum, Person, Entwurf einer phänomenologischen Anthropologie, Klett-Cotta, Stuttgart, 2000.

Günzel, S.: Topologie, Zur Raumbeschreibung in den Kultur und Medienwissenschaften, Transcript, Bielefeld, 2007.

Haegens, K.: Wie is Peter Sloterdijk?, available at: https://www.groene.nl/artikel/wie-is-peter-sloterdijk, last access: 1 May 2017.

Heidegger, M.: Being and Time, HarperPerennial, New York, 2008 [1927].

Hellmann, K.-U.: Grenzen der Gemeinschaft, Helmuth Plessner, René König und Joseph R, Gusfield, available at: http://www.markeninstitut.de/fileadmin/user_upload/ dokumente/Grenzen.pdf (last access: 1 May 2017), 2008.

Henkel, A.: Posthumanism, the Social and the Dynamics of Material Systems, Theor. Cult. Soc., 33, 65-89, 2016.

Hetzel, A.: Der Mensch als "praktischer Anspruch", Zum Primat des Politischen in Helmuth Plessners Anthropologie, in: Zwischen Anthropologie und Gesellschaftstheorie, Zur Renaissance Helmuth Plessners im Kontext der modernen Lebenswissenschaften, edited by: Gamm, G., Gutmann, M., and Manzei, A., Transcript, Bielefeld, 233-258, 2005.

Hui, A., Schatzki, T., and Shove, E. (Eds.): The Nexus of Practices, Connections, constellations, practitioners, Routledge, Oxon, 2017.

Korf, B. and Wastl-Walter, D.: Kultur und Politik, in: Humangeographie kompakt, edited by: Freytag, T., Gebhardt, H., Gerhard, U., and Wastl-Walter, D., Springer, Berlin, 2016.

Krüger, H.-P.: Kritische Anthropologie? Zum Verhältnis zwischen Philosophischer Anthropologie und Kritischer Theorie, Deut. Z. Philos., 64, 553-580, 2016.

Lemmens, P. and Zwart, H.: Sloterdijk in vogelvlucht, Wijsgerig Perspectief, 44, 4-13, 2004.

Lindemann, G.: Doppelte Kontingenz und reflexive Anthropologie, Z. Soziol., 28, 165-181, 1999.

Lindemann, G.: Weltzugänge: Die mehrdimensionale Ordnung des Sozialen, Velbrück Wissenschaft, Weilerswist, 2014.

Lindemann, G.: Die Sphäre des Menschen, in: Helmuth Plessner: Die Stufen des Organischen und der Mensch, edited by: Krüger, H.-P., De Gruyter, Berlin, 163-177, 2017.

Malpas, J.: Heidegger and the Thinking of Place: Explorations in the Topology of Being, MIT Press, Cambridge, 2012.

Malpas, J.: Re-Orienting Thinking: Philosophy in the Midst of the World, in: Commonplace Commitments: Thinking Through the Legacy of Joseph P, Fell, edited by: Fosl, P. S., McGandy, M. J., and Moorman, M. D., Bucknell University Press, Lewisburg, 169-188, 2016.

Malpas, J.: In the Vicinity of the Human, Int. J. Philos. Stud., 25, 423-436, 2017.

Mauthner, F.: Zur Sprache und Zur Psychologie, Beiträge zu einer Kritik der Sprache, 1, Cotta'sche Buchhandlung, Stuttgart, 1906.

Metcalfe, A. and Ferguson, L.: Half-opened being, in: Timespace: Geographies of temporality, edited by: May, J. and Thrift, N., Routledge, London, 2001.

Morin, M.-E.: Cohabitating in the globalised world: Peter Sloterdijk's global foams and Bruno Latour's cosmopolitics, Environ. Plann. D, 27, 58-72, 2009.
Morin, M.-E.: The coming-to-the-world of the Human Animal, in: Sloterdijk Now, edited by: Elden, S., Polity Press, Malden, 7795, 2012.

Musil, R.: The Man Without Qualities, Pan Macmillan, London, 2017.

Nicolini, D.: Practice theory, work, and organization: an introduction, Oxford University Press, Oxford, 2013.

Nietzsche, F.: Menschliches, Allzumenschliches, I, Moral als Selbstzerteilung des Menschen, Kritische Studienausgabe KSA, 2, $76,1886$.

Nieuwenhuis, M.: Taking up the challenge of space: New conceptualisations of space in the work of Peter Sloterdijk and Graham Harman, Continent, no. 4.1, 17-37, available at: http://www.continentcontinent.cc/index.php/continent, last access: 1 May 2017

Noordegraaf-Eelens, L. and Schinkel, W.: De inspirerende ruimte van Peter Sloterdijk, Krisis, 2, 84-93, 2005.

Plessner, H.: Die Stufen des Organischen und der Mensch, Einleitung in die philosophische Anthropologie, De Gruyter, Berlin, 1975 [1928].

Plessner, H.: The Limits of Community: A Critique of Social Radicalism, Humanity Books, New York, 1999 [1924].

Reckwitz, A.: Toward a Theory of Social Practices, A Development in Culturalist Theorizing, Eur. J. Soc. Theory, 5, 243-263, 2002.

Reckwitz, A.: Affective spaces: a praxeological outlook, Rethinking History, Journal of Theory and Practice, 16, 241-258, 2012.

Richter, N. A.: Grenzen der Ordnung, Bausteine einer Philosophie des politischen Handelns nach Plessner und Foucault, Campus, Frankfurt am Main, 2005.

Romano, C.: Slippery Sloterdijk: the Edgy European Philosopher, Circa 2012, in: The Chronicle of Higher Education, 5 November 2012

Schäfer, H. (Ed.): Praxistheorie, Ein soziologisches Forschungsprogramm, Transcript, Bielefeld, 2016.

Schatzki, T. R.: Introduction: practice theory, in: The practice turn in contemporary theory, edited by: Schatzki, T. R., Knorr Cetina, K., and von Savigny, E., Routledge, London, 1-14, 2001.

Schatzki, T. R.: The site of the social: a philosophical account of the constitution of social life and change, Pennsylvania State University Press, University Park, 2002.

Schatzki T. R.: A primer on practices, in: Practice-based education: perspectives and strategies, edited by: Higgs, J., Barnett, R., Billett, S., Hutchings, M., and Trede, F., Sense, Rotterdam, 13-26, 2012.

Scheer, M.: Are Emotions a Kind of Practice and Is That What Makes Them Have a History? A Bourdieuian Approach to Understanding Emotion, Hist. Theory, 51, 193-220, 2012.

Schmitz, H.: Der Leib, der Raum und die Gefühle, Aisthesis, Bielefeld, 2007.

Schmitz, H.: Kurze Einführung in die neue Phänomenologie, Karl Alber, Freiburg, 2010.

Schmitz, H., Müllan, R. O., and Slaby, J.: Emotions outside the box - the new phenomenology of feeling and corporeality, Phenomenol. Cogn. Sci., 10, 241-259, 2011.

Shove, E., Pantzar, M., and Watson, M.: The Dynamics of Social Practice: Everyday life and how it changes, Sage, London, 2012.

Sloterdijk, P.: Spheres, Volume I: Bubbles Microspherology, Semiotexte, Los Angeles, 2011. 
Sloterdijk, P.: Nearness and Da-sein: The Spatiality of Being and Time, Theor. Cult. Soc., 29, 36-42, 2012.

Sloterdijk, P.: Spheres, Volume II: Globes Macrospherology, Semiotexte, Los Angeles, 2014.

Sloterdijk, P.: Selected Exaggerations: Conversations and Interviews 1993-2012, Polity, Cambridge, 2016a.

Sloterdijk, P.: Spheres, Volume III: Foams Plural Spherology, Semiotexte, Los Angeles, 2016b.

Tarde, G.: The Laws of Imitation, Henry Holt, New York, 1903 [1890].
Thrift, N.: Different atmospheres: of Sloterdijk, China and site, Environ. Plann. D, 27, 119-138, 2009.

Tönnies, F.: Community and Society, Dover Publications, Mineola, 2011 [1887].

van Tuinen, S.: Sloterdijk binnenstebuiten denken, Klement, Kampen, 2004.

van Tuinen, S.: Peter Sloterdijk: Ein Profil, Fink, Paderborn, 2006. van der Ven, B.: Sferen en globalisering, Ethische aspecten van Sloterdijks bijdrage aan het globaliseringsdebat, Tijdschr Filos, 64, 479-507, 2002. 